\title{
Using Google form for Student Worksheet as Learning Media
}

\author{
Muhammad Iqbal $^{1}$, Janner Simarmata ${ }^{1}$, F Feriyansyah ${ }^{1}$, Anna Riana Suryanti Tambunan ${ }^{1}$, Onggal Sihite ${ }^{1}$, Apiek \\ Gandamana $^{1}$, Gita Noveri Eza ${ }^{1}$, Fauzi Kurniawan ${ }^{1}$, A Asiah ${ }^{1}$, Fahrur Rozi ${ }^{1}$, F Faisal ${ }^{1}$, Imelda Free Unita Ma- \\ nurung ${ }^{1}$, Mohamad Ihwani ${ }^{1}$, Putri Lynna Adelinna Nathan ${ }^{1}$, Nathanael Sitanggang ${ }^{1}$, Naeklan Simbolon ${ }^{1}$, Eva \\ Betty Simanjuntak ${ }^{1}$, Tonni Limbong ${ }^{2}$ \\ ${ }^{1}$ Universitas Negeri Medan, Medan - Indonesia \\ ${ }^{2}$ Universitas Katolik Santo Thomas Medan, Medan-Indonesia \\ *Corresponding author E-mail: iqbal81@unimed.ac.id
}

\begin{abstract}
This study aims to describe the creation of student worksheets using Google forms. The problem in this study is how the steps for creating student worksheets through the Google form and the structure of the worksheet produced. The method in this study uses qualitative descriptive types. Research subjects are instructors who use the Google forms as learning media. The researchers obtained the data through observation, in-depth interviews, and review of various document sources. The results of the study illustrate the steps in making student worksheets having the stages of preparation, design, and implementation. Some forms of worksheets produced, namely narrative models, audio-visuals and links.
\end{abstract}

\section{Introduction}

A common problem that often occurs for teachers at universities is the difficulty in organizing student tasks effectively and efficiently[1][2]. This problem is indicated by the presence of teachers using conventional methods in the learning process, such as sending and receiving student assignments in physical form (using paper) [3]-[7] With the development of technology, today forms of physical learning can be transformed into online forms [8]-[11]. One application that can be used is to use the Google form. Google form is an application that is provided by Google in a free (free) way to meet the needs of users in the form of templates and has various functions and uses [12]-[16].

Teacher difficulties can be overcome by using the Google form. Various forms of forms provided can be used for learning purposes such as surveys, exam forms, activity sheets which can all be done online (paperless). Learning will also be more exciting and interactive [1], [17]-[22].

Meanwhile, the use of Google forms in learning has its impact, which is managing student tasks to be more efficient. More than that can be used to prepare/make worksheets following the wishes and needs of the teacher.

Thus this research attempts to describe the process of creating student worksheets through the google form and knowing the type of the worksheet produced [23][24].

\section{Research Method}

This study uses qualitative research methods with descriptive types. The study seeks to describe and understand the meaning that comes from individuals and groups [25][26]. In this study, data were collected through classroom observations, conducting in-depth interviews with research subjects, namely teachers in the study program of anthropology education, Medan State University that uses the google forms explicitly as a medium in making student worksheets. Next, review document sources relating to similar research results through journals, textbooks and search engines on the internet.

\section{Review of Literature}

Research on the use of Google as a learning media, evaluation, registration form and assignment has been carried out by several researchers [27]-[31].

The research conducted by Coal was entitled the Use of Google Form as a Tool for Assessing Lecturer Performance in the UNISKA PGMI Study Program Muhammad Arsyad Al Banjari [27]. The results of the research carried out describe the procedure for developing lecturers' performance appraisal questionnaires through the Google Form starting from the stage of planning, creating, publishing and providing instructions for use. Furthermore, students like the use of online surveys which are considered easily accessible, efficient, save paper and have an attractive appearance.

Research conducted by Fauzi entitled Use of Google Form as a Learning Evaluation Tool in Indonesian Language Subjects (Analytical-Descriptive Studies in Class VIII of SMP Negeri 1 Lembang) [28]. This study explains the use of Google Form evaluation tools is expected to provide convenience in learning evaluation activities both from planning evaluation to efficiency, effectiveness, and attractiveness for teachers and students.

Research conducted by Fatria and Listari, entitled Application of Google Drive Learning Media in Indonesian Language Learning. In the study explained Google Drive could improve the teaching and learning process to be active and innovative and become learning-based learning [30]. 
The study was conducted by Iqbal, M, Rosramadhana, Amal, B.K, Rumapea, M.E, entitled Use of Google Form as Media for Assignment of Introductory Subjects to Social Sciences. In his research describes the google form as a medium in assigning Social Sciences courses. The assignment can be done online through the link [31].

Rahardja, Untung, Lutfiani, Ninda, Sandi Alpansari, Moch [29] entitled Utilization of Google Forms as a Member Registration System on the Aptisi.or.id Website. This research describes the google form as a form-based facility to obtain data/information through questionnaires and registration. By registering through google form, it is more efficient and effective.

Various initial studies have been conducted so this research is in line with previous research, and this research focuses more on the process of making student worksheets through the google form and some forms/models that can be used for teachers.

\section{Result and Discussion}

Based on the research results the process of making student worksheets is done through several stages, namely:

\subsection{Preparation Stages}

At this preparation stage several things that are needed, namely:

1. Prepare an operational device, such as a computer, laptop, smartphone, tablet, etc. (choose one).

2. Instruments used are connected to the internet network.

3. Have a Google email account

4. Semester learning plan documents

\subsubsection{Design Stages}

Before the implementation of the worksheet, the content of the worksheets is desired, such as assignment identity, student Name, and ID, the content of worksheets (text/narration, image / visual, web links, videos, etc.), selection of the desired template form. To fill in the content of worksheets adjusted to the topics taken from the semester learning plan.

\subsubsection{Implementation Phase}

To open and run google forms can be done in 2 (two) ways, namely first accessing through the search engine and the second entering through the Gmail account that was previously owned. To access via the search engine by typing the keyword "google form." Meanwhile via an email account by opening the google drive feature and selecting the google forms menu.

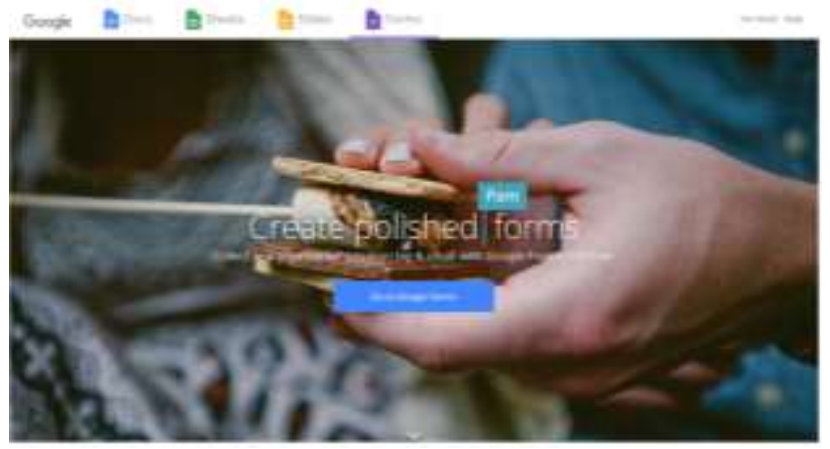

Fig.1: Front page view of Google Forms

After entering the Google form page (figure 1), some template characteristics are presented, such as education, personal and work activities (figure 2). The templates provided are patterned document models that can be used/adapted to the desired design. Selecting a template in making the worksheet will automatically adjust the chosen template. In the template, there will be parts (features) that help and support in designing the desired worksheet.

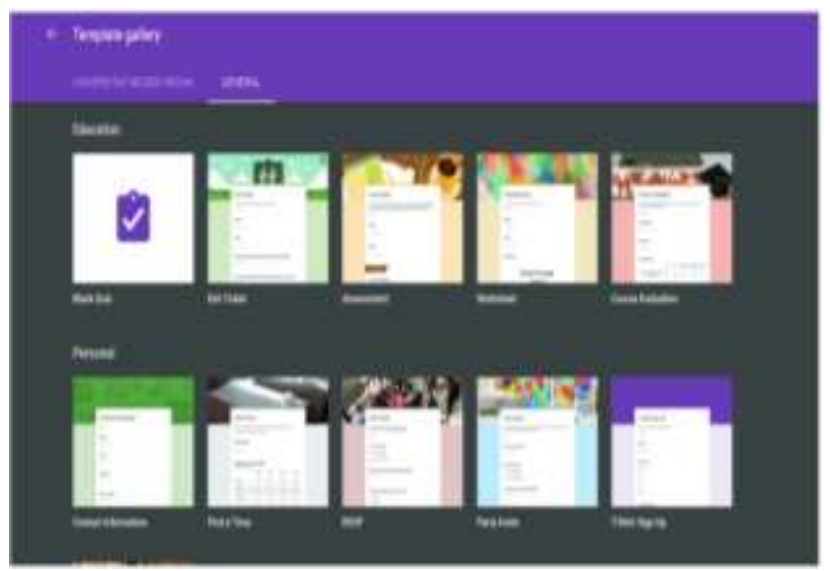

Fig. 2: Template provided by Google form

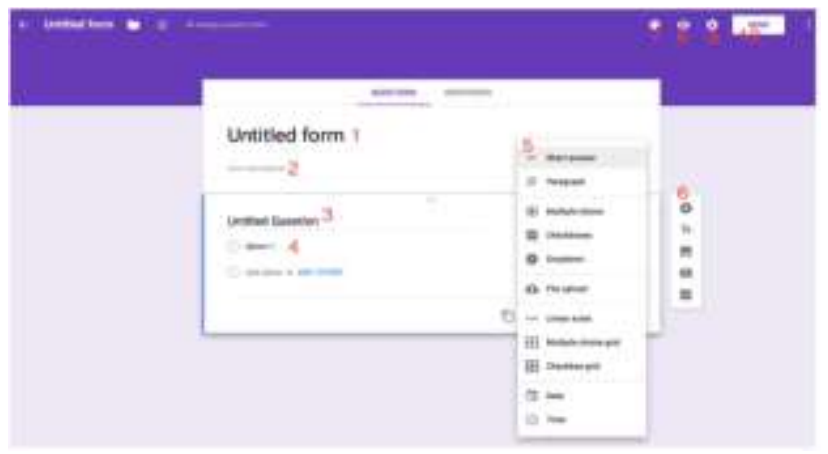

Fig. 3: Google form worksheets

After selecting one of the templates and entering into the Google form, some parts need to be known (Figure 3), namely:

1. The top section of a Google form sheet contains the Untitled text form which is part of writing the title of the desired worksheet. Only by deleting/overwriting the untitled form, the writing will automatically change.

2. This section is a description of a sheet used. It is generally used to provide concise information on worksheet users.

3. This section is a format of questions that can be modified by writing/quoting the untitled Question with a question statement.

4. The answer column for worksheet questions.

5. Options for the model of the desired answer, such as short answers, long answers (paragraphs), multiple choices, checkboxes, upload files or use a scale.

6. Providers help to add desired parts such as questions, titles, and descriptions, insert images/photos, videos, and add/multiply parts of the worksheet page.

7. This section is to change the color, background, and form of writing.

8. This section is to see the overall temporary appearance

9. Arrangements for managing worksheets, such as restrictions on sending worksheets to users, rearranged by the user before the sheet is sent and manipulating the text of the recipient of the worksheet.

10. This section of the worksheet is ready to be sent to users (students) which can be done via email, individuals/collectives, links and sharing on social media (Google+, Facebook and Twitter). Each worksheet creation is stored automatically and stored in a folder.

\subsection{Worksheet Models}

Based on the final results of the worksheet, some models are produced, namely. 


\subsubsection{Narrative Model}

This worksheet is designed to analyze a problem that is given narratively (figure 4). In its use students merely open and access the links that have been provided https://goo.gl/forms/kKWT6CcRlHNiwDkH3.

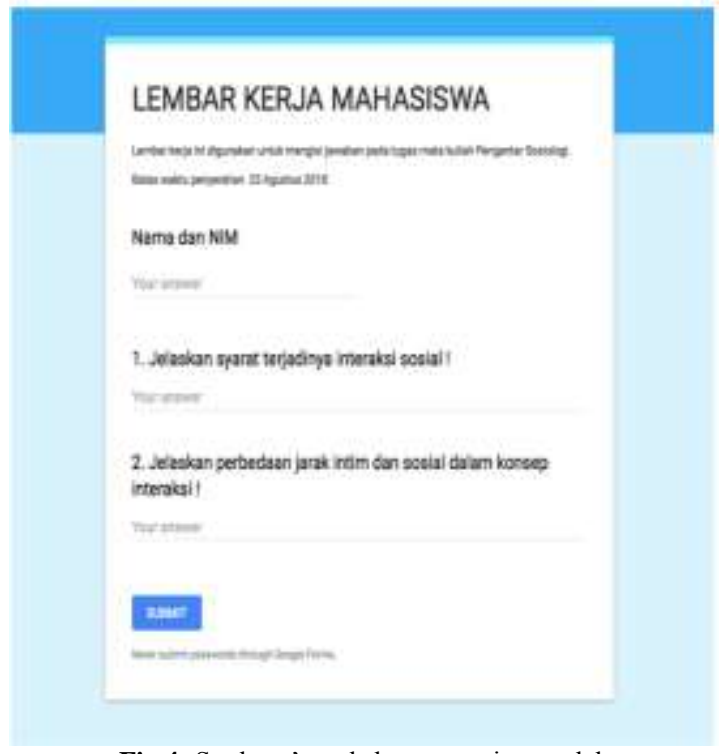

Fig.4: Students' worksheet narrative model

\subsubsection{Audio-Visual Model}

This worksheet is designed to include video content that contains audio-visuals. In this worksheet, videos can be observed and played directly. Students see the video content that is included. Thus the video content can be used as a source of analysis. To open and access the worksheet, students begin the worksheet (figure 5) through the link https://goo.gl/forms/irHBf5lhEX2SfKHn1

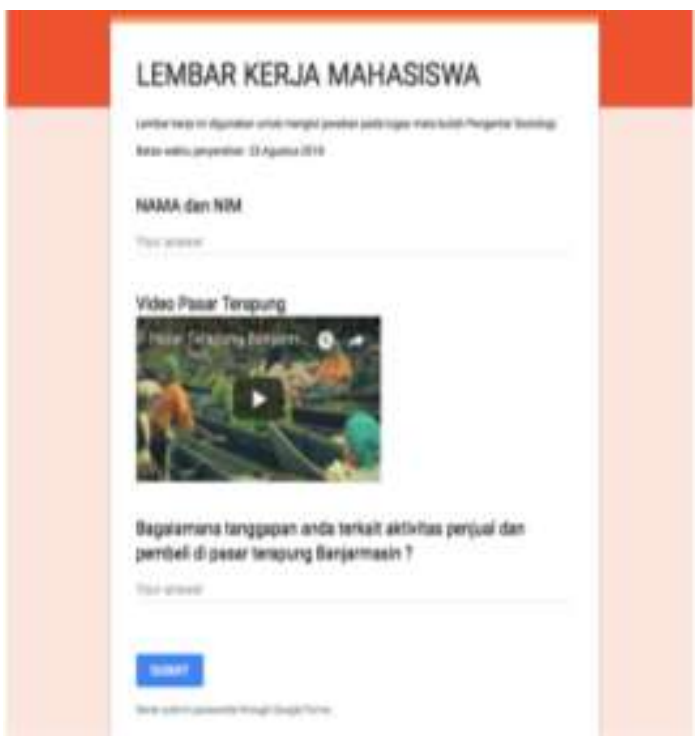

Fig.5: Students' worksheet audio-visual model

\subsubsection{Link Model}

This worksheet is designed for students in carrying out tasks related to the review of documents, such as journals and electronic books. Teachers can list and link links from specific sources that can be accessed directly (figure 6). To open this worksheet students need to open links https://goo.gl/forms/r9RxC5P2YbLCzWAz2.

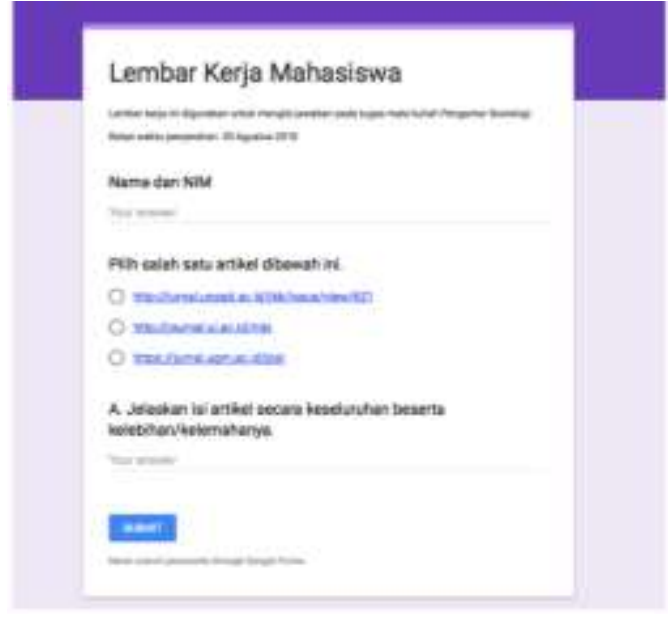

Fig.6: Student worksheet link model

Some models of worksheets produced can be used directly, and the teacher does not need a physical worksheet (paper) in sending and receiving student assignments.

\section{Conclusions}

From the results of this study, it is briefly explained again that the creation of student worksheets requires the stages in the process and produces several forms of worksheet models that can be tailored to the needs. Besides, teachers and students are more accessible in the process of sending and receiving worksheets that are done online. By preparing worksheets through the Google form, it creates a stimulating, interactive learning environment and saves time.

\section{References}

[1] D. Napitupulu et al., "Analysis of Student Satisfaction Toward Quality of Service Facility," J. Phys. Conf. Ser., vol. 954, no. 1, 2018.

[2] I. Irfandi, F. Faisal, N. I. Hasibuan, and D. D. Panggabean, "THE DISSEMINATION OF TECHNOLOGY-BASED LEARNING MEDIA FOR ELEMENTARY SCHOOL TEACHERS IN THE DISTRICT OF SIJUNJUNG,” J. Community Res. Serv., vol. 2, no. 1, pp. 198-205, Aug. 2018.

[3] S. Sriadhi, S. Gultom, R. Restu, and J. Simarmata, "The Effect of Tutorial Multimedia on the Transformator Learning Outcomes Based on the Students' Visual Ability," in IOP Conference Series: Materials Science and Engineering, 2018, vol. 384, no. 1.

[4] T. Limbong et al., "The Implementation of Multi-Objective Optimization on the Basis of Ratio Analysis Method to Select the Lecturer Assistant Working at Computer Laboratorium," Int. J. Eng. Technol., vol. 7, no. 2.13, pp. 352-356, Apr. 2018.

[5] I. K. Sudarsana et al., Pengembangan Media Pembelajaran Berbasis Teknologi Informasi, vol. 8, no. 2. Jayapangus Press, 2018.

[6] R. Rahim et al., "Internet based remote desktop using INDY and socket component," Int. J. Eng. Technol., vol. 7, no. 2.9, pp. 44-47, 2018.

[7] W. Pintalitna, H. Sipahutar, and F. Harahap, "DESIGNING INTERACTIVE DIGITAL LEARNING MODULE IN BIOLOGY," TABULARASA, vol. 12, no. 2, Aug. 2015.

[8] J. Simarmata, "Pengenalan Teknologi Komputer dan Informasi," Yogyakarta Andi, 2006.

[9] J. Simarmata, Rekayasa Perangkat Lunak. Penerbit Andi, 2010.

[10] J. Simarmata, A. Djohar, J. P. Purba, and E. A. Djuanda, "Perancangan Prototype Model Pembelajaran Berbasis Blended Learning Untuk Meningkatkan Proses Pembelajaran,” 2017.

[11] J. Simarmata, A. Djohar, J. P. Purba, and E. A. Djuanda, "IMPLEMENTASI MODEL PEMBELAJARAN BERBASIS BLENDED LEARNING UNTUK MENINGKATKAN HASIL BELAJAR SISWA."

[12] Zaenal; Ali, Buku Pintar Google. Jakarta: Media Kita, 2011.

[13] D. "DK" Kim and C. Park, "Gender differences in the effectiveness of Google Forms in class,” J. Instr. Pedagog., vol. 7, pp. 1-9, 2012. 
[14] L. Laskowski, "Google Forms and Sheets for library gate counts," J. Access Serv., vol. 13, no. 3, pp. 151-158, Jul. 2016.

[15] M. P. A. Murphy, "\&quot;Blending\&quot; Docent Learning: Using Google Forms Quizzes to Increase Efficiency in Interpreter Education at Fort Henry," J. Museum Educ., vol. 43, no. 1, pp. 47-54, Jan. 2018.

[16] J. Simarmata, A. Djohar, J. Purba, and E. A. Juanda, "Design of a Blended Learning Environment Based on Merrill's Principles," J. Phys. Conf. Ser., vol. 954, no. 1, 2018.

[17] J. Simarmata et al., "Prototype Application Multimedia Learning for Teaching Basic English,” Int. J. Eng. Technol., vol. 7, no. 2.14, pp. 264-266, Apr. 2018.

[18] N. B. S. Wangi et al., "Gamification framework and achievement motivation in digital era: Concept and effectiveness," Int. J. Eng. Technol., vol. 7, no. 3.6 Special Issue 6, 2018.

[19] M. B. N. Wajdi et al., "Advancement of E-Book Through Automation System in Department of Islamic Education (STAI) Miftahul Ula Nganjuk," Int. J. Eng. Technol., vol. 7, no. 3.6, pp. 438-441, Jul. 2018.

[20] J. Simarmata, T. Limbong, A. R. S. Tambunan, M. P. Simanjuntak, and R. Limbong, "Multimedia of Number Recognition for Early Childhood Using Image Object," vol. 7, pp. 796-798, 2018.

[21] J. Simarmata et al., "Learning application of multimedia-basedcomputer network using computer assisted instruction method," Int. J. Eng. Technol., vol. 7, no. 2.13 Special Issue 13, 2018.

[22] . H., R. Dwi Suyanti, and R. D. Suyanti, "EFFECTS OF INQUIRY TRAINING LEARNING MODEL BASED MULTIMEDIA AND MOTIVATION OF PHYSICS STUDENT LEARNING OUTCOMES,” J. Pendidik. Fis., vol. 2, no. 1, p. 25, Jun. 2013.

[23] R. Silaban, M. Pasaribu, S. M. Sitompul, and T. W. Simanullang, "Inovasi Lembar Kerja Siswa Reaksi Redoks Berbasis Pemecahan Masalah Untuk Siswa SMA,” J. Pendidik. Kim., vol. 8, no. 1, pp. 65-70, 2016.

[24] R. Silaban, S. M. Sitompul, M. E. Pasaribu, and T. W. Simanullang, "Penyediaan Lembar Kerja Siswa Inovatif Larutan Elektrolit dan Non Elektrolit Untuk Siswa SMA,” J. Pendidik. Kim., vol. 7, no. 3, pp. 13-17, 2015.

[25] Creswell;John W, Research Design Pendekatan Metode Kualitatif Kuantitatif dan Campuran ed.4 Pustaka Pelajar. Jogyakarta: Pustaka Pelajar, 217AD.

[26] A. S. Ahmar et al., "Modeling Data Containing Outliers using ARIMA Additive Outlier (ARIMA-AO)," J. Phys. Conf. Ser., vol. 954, no. 1,2018

[27] H. H. Batubara, "Penggunaan Google Form Sebagai Alat Penilaian Kinerja Dosen di Prodi PGMI Uniska Muhammad Arsyad Al Banjari."

[28] M. R. Fauzi, "PENGGUNAAN GOOGLE FORM SEBAGA ALAT EVALUASI PEMBELAJARAN PADA MATA PELAJARAN BAHASA INDONESIA : Studi Deskriptif Analitis pada Kelas VIII di Sekolah Menengah Pertama Negeri 1 Lembang," Jan. 2014.

[29] U. Rahardja, N. Lutfiani, and M. S. Alpansuri, "Pemanfaatan Google Formulir Sebagai Sistem Pendaftaran Anggota Pada Website Aptisi.or.id," SISFOTENIKA, vol. 8, no. 2, pp. 128-139, Jul. 2018.

[30] F. Fatria and U. M. N. Al-washliyah, "PENERAPAN MEDIA PEMBELAJARAN GOOGLE DRIVE DALAM,” vol. 2, no. 1, 2017.

[31] M. Iqbal, R. Rosramadhana, B. K. Amal, and M. E. Rumapea, "Penggunaan Google Forms Sebagai Media Pemberian Tugas Mata Kuliah Pengantar Ilmu Sosial," JUPIIS J. Pendidik. Ilmu-ilmu Sos., vol. 10, no. 1, pp. 120-127, 2018. 